\title{
The Free Hajj: Virtual Reality in Manasik Hajj Training Education
}

\author{
*Dadan Sumardani ${ }^{1}$, RahmaRosaliana Saraswati ${ }^{2}$, \\ UlfatunWidiastuti $^{3}$, Komala $^{4}$, WindaDewiListyasari ${ }^{5}$ \\ ${ }^{1}$ National Chiayi University, Chiayi City, Taiwan \\ ${ }^{2,3,4,5}$ Universitas Negeri Jakarta, Rawamangun, Jakarta, Indonesia \\ *s1090815@mail.ncyu.edu.tw
}

\begin{abstract}
Hajj is one of the five pillars of Islam and is obligatory for qualified Muslims. This study aims to make a virtual reality application for hajj simulation. This study uses descriptive analysis method.The result of this research is an application that consists of 6 features, namely: features (hajj series, hajj series guide, Arabic language, floor plans, frequently asked questions, instructions for use).The Free Hajj will learn how to perform the Hajj not just a theory but also presents ideas, practices and actual conditions, like being directly in Mecca.
\end{abstract}

Haji adalah salah satu dari lima rukun Islam dan wajib bagi Muslim yang berkecukupan. Penelitian ini bertujuan untuk membuat aplikasi virtual reality untuk simulasi haji. Penelitian ini menggunakan metode analisis deskriptif. Hasil dari penelitian ini berupa aplikasi yang terdiri dari 6 fitur, yaitu: fitur (rangkaian haji, seri panduan haji, bahasa arab, denah lantai, tanya jawab, petunjuk penggunaan). akan belajar bagaimana menunaikan haji tidak hanya teori tetapi juga menyajikan ide, amalan dan kondisi aktual, seperti berada langsung di Mekah.

Keywords:Hajj, Simulation, Virtual Reality.

Received: November 30, 2020; Revised:December30, 2020; Accepted:January5, 2021

\section{INTRODUCTION}

Hajj is one of Islam's five pillars and is obligatory for qualified Muslims(Mulyana and Gunawan, 2010). This order is contained in the word of Allah SWT in the Al-Quran surah Ali Imran verse 97. Indonesia has become one of the countries with the largest number of haj quota given by the government of the Kingdom of Saudi Arabia for 2018, reaching 221,000 congregations(Humas Setkab, 2019). This data shows that the interest of the Indonesian people towards Hajj is very high.

The process of preparing for the departure of the Hajj is very long, so it is necessary to carry out a long preparation to carry out this obligation. However, the priority of government preparations being carried out is more targeting ways to perform Hajj(Masruroh and Ma'ruf, 2020). This priority is evident from the decree of the Director-General of Hajj and Umrah Organizing that Hajj rituals are held at least ten times, namely eight times at the sub-district Office of Religious Affairs (KUA), and two times in Regency / City for areas outside Java. Whereas on the island of Java, the 
Hajj rituals are held six times at the Office of Religious Affairs and two times at the Regency/City level(JPPN, 2019).

Hajj rituals are the procedures or practices for the pilgrimage. The goal is that the pilgrims will not be confused in carrying out various Haj processions in the holy land. However, even though this has been done by prospective pilgrims in the country when they arrive in the sacred land, many are still confused about the implementation and procedures related to the pilgrimage(Ridarineni, 2014). many pilgrims face many difficulties and problems to perform the Hajj due to lack of knowledge and weaknesses towards Hajj's practical steps(Model, Persuasive and Learning, 2015).

Complaints about the difference between conditions during rituals and in the holy land must be resolved. Virtual reality is an artificial environment created using software and presented to the user to suspend belief and accept it as a real environment(Yasin et al., 2010). The simplest form of virtual reality is a 3D image that can be explored interactively at a personal computer, usually by manipulating keys or the mouse so that the image's content moves in some direction or zooms in or out(Mohd et al., 2012).A technology company has developed a virtual reality technology on carrying out Hajj and Umrah from Pakistan in 2019. This digital technology has facilitated thousands of Pakistani pilgrims to perform Hajj correctly, such as carrying out the real Hajj through virtual reality (VR) technology(Huda, 2019). This system's results have the advantage of presenting direct interaction with the hajj and umrah processions simulated by a computer. Unfortunately, these VR products are costly for individuals to reach because the price is around fifteen million for one simulation device(Rif, 2020).

The news about VR development has also surfaced in August 2019, which the NU Organization discussed. This plan is intended to make it easier forNahdlatul 'Ulama (NU) to equip Hajj participants in performing Hajj rituals. Unfortunately, this plan has not been realized due to funding problems and the Virtual Reality application development team(nu.or.id, 2019).

This Virtual Realityofmanasik of Hajj has the main objective of making it easier for pilgrims to understand the Hajj material using their smartphones. Hajj rituals will guide Hajj rituals in an easily accessible way and practice in a virtual environment very similar to the holy land(Achmad, 2020). Based on the background stated above, the authors are interested in making a Virtual Reality application used to help the learning process of Hajj rituals.

\section{METHOD}

The method used in this article is descriptive analysis method. The descriptive analysis method is a method for analyzing data by describing or describing the data that has been collected as it is without intending to make generalized conclusions or generalizations(Sugiono, 2017). The researcher took the first step, namely needs analysis. Needs analysis is carried out to determine what features are required to design The Free Hajj application. The needs analysis was carried out using the 2019 Hajj congregational interview technique, discussions with material experts and media experts, and literature study.

The next step is designing or designing a system using a case diagram that explains that the actors involved are the hajj registrant community who acts as an application 
user or user, entity relational diagrams and mockups. After designing, the next stage is construction and development and then performs the interface results. The following is the flow of the Free Hajj application system design formulation in Figure1.

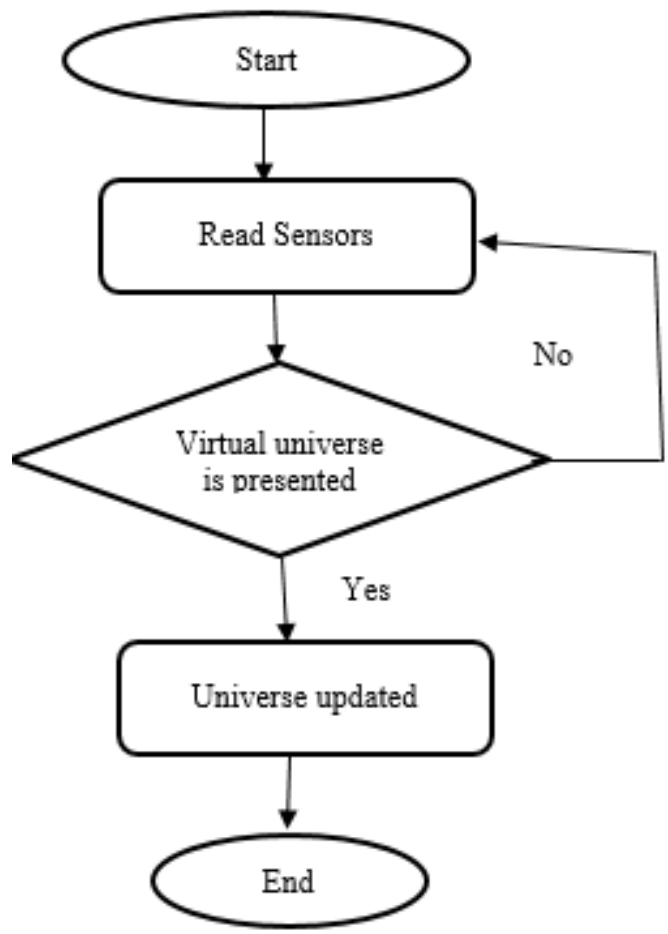

Figure 1. Design System of Application of The Free Hajj

\section{RESULT AND DISCUSSION}

\section{Explanation of application feature content}

The Free Hajj application design consists of 6 (six) features, namely, material features containing $360^{\circ}$ virtual reality videos, pilgrimage guidelines features, floor plan features, and conversation features in Arabic, question and answer features and application guide features. Here is a splash screen from The Free Hajj application (Fig. 2).

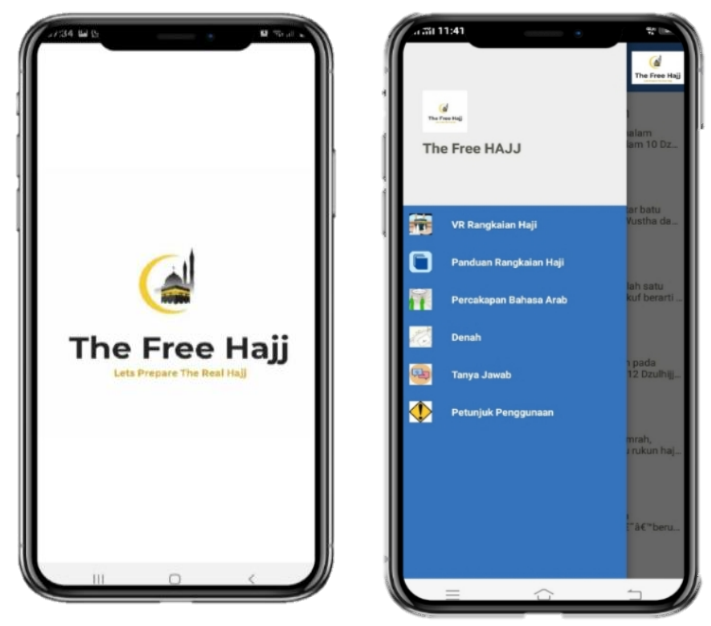

Figure 2. Mock Up of Splash Screen 


\section{Hajj Series VR Features}

The Hajj Series VR feature is the main feature of this application. In this feature, there is a 360-degree video of the Hajj series. I am starting from the introduction to the Hajj to tawaf wada. Also, on this VR, there is an audio narrative explanation in each series. The following is a screen display of this feature.

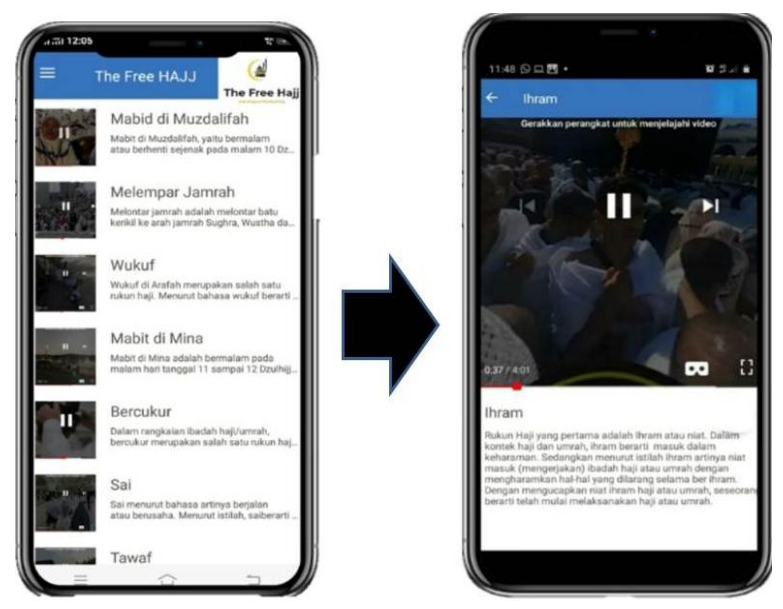

Figure 3. Mock Up ofVR Feature

When the video is played, the smartphone is inserted into the VR Box, and then the display will appear as follows in Figure 4.

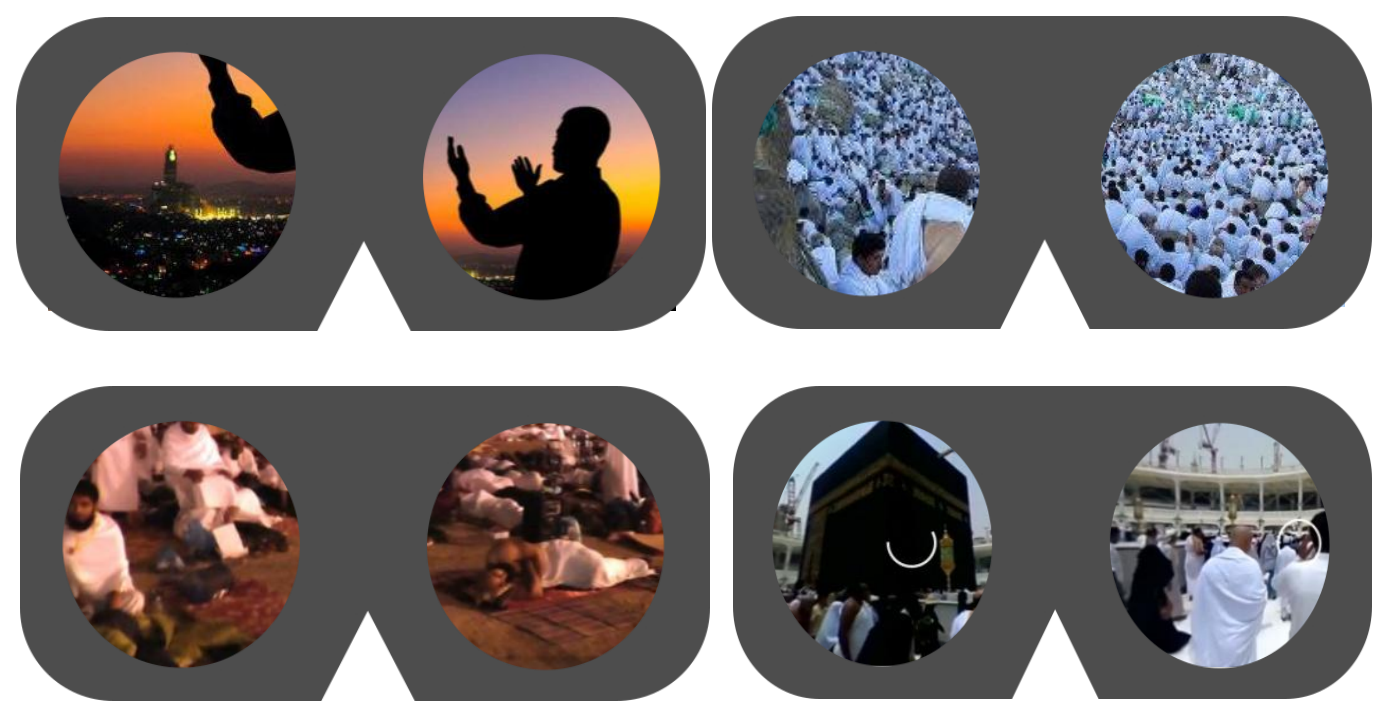

Figure 4. Mock Up ofVR Screen in VR Box 


\section{Hajj Series Guide}

This feature contains a guide to the three types of Hajj series: the teammate, ifrad, and qiran Hajj textually (Fig. 5).

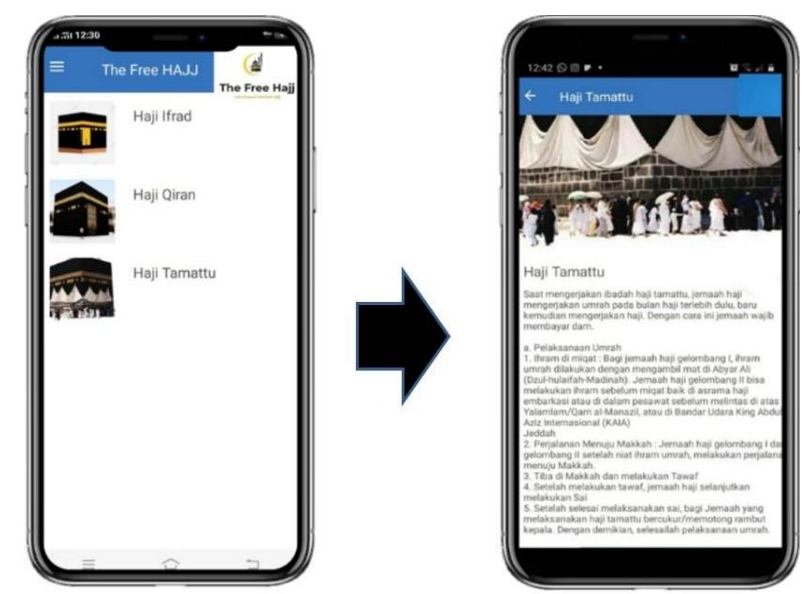

Figure 5. Mock Up ofInstructure for VR HAJJ

\section{Hajj Conversation Features}

This feature contains information on conversations that the congregation can carry out in the holy land in Figure 6. This feature includes a practical thematic dictionary and essential expressions in Arabic. A useful thematic dictionary contains Arabic words (it can be called an Arabic dictionary) and important phrases containing sentences/questions often needed when in the holy land in Figure 6.

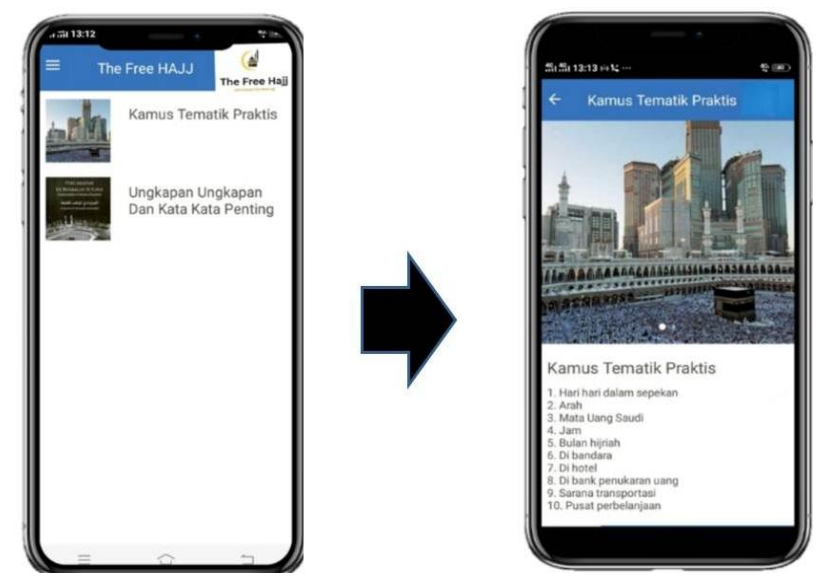

Figure 6. Mock Up ofHajj Conversation 


\section{Maps Features}

This plan feature consists of Mecca and Medina's detailed city plans such as the entrances to the Grand Mosque and the doors to the Nabawi mosque so that the pilgrims do not easily get lost in the holy land (Fig. 7).

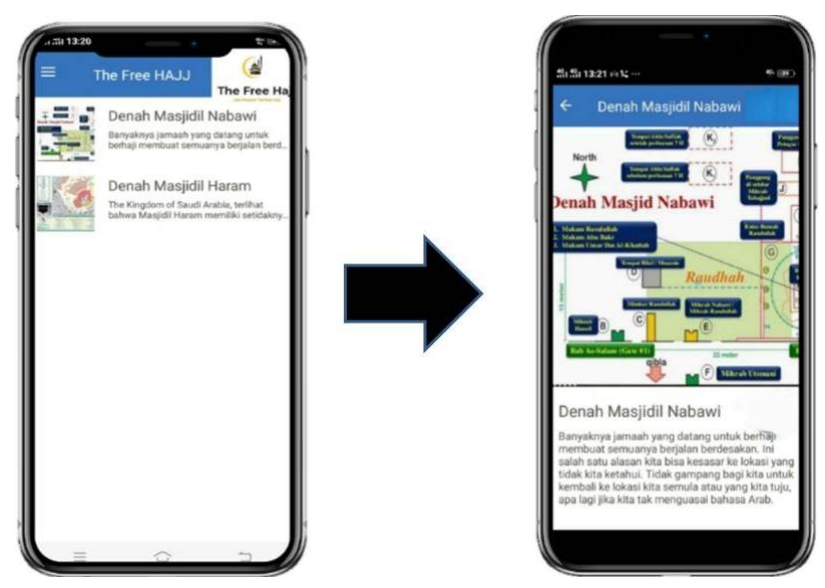

Figure 7. Mock Up ofMaps Feature

\section{Question and Answer feature}

In this feature, some questions are most often asked by pilgrims about the procedures for Hajj rituals and answers (Fig. 8).

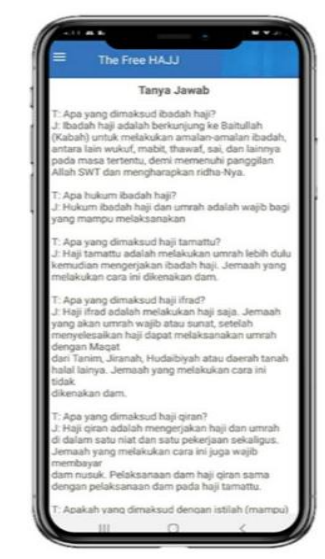

Figure 8. Mock Up of $Q \& A$ Features

\section{User Guide Features}

The user guide feature contains instructions for using the application. The way to use the application is as follows in Figure 9.

1. Setting up VR Box.

2. Installing The Free Hajj application on Android with Gyroscope support on the device.

3. Enter The free Hajj application and select the VR Series of Hajj menu

4. Then enter the Android into the VR Box.

5. The virtual reality-based Hajj rituals are ready to run. 


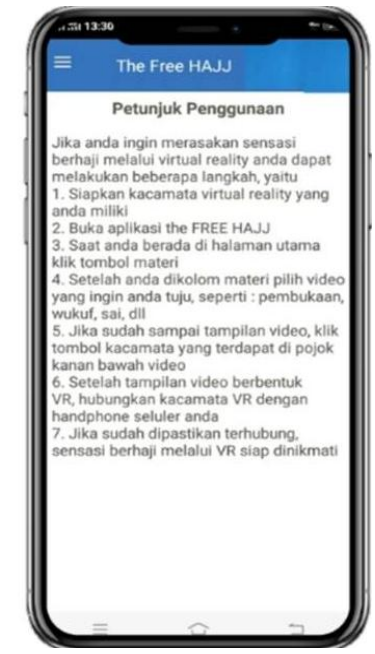

Figure 9. Mock Up ofUser Guide Features

\section{The advantages of The Free Hajj Application}

The following are the advantages of The Free Hajj application compared to other Hajj rituals simulation. Theadvantage of this application is presenting a complete series of Hajj, equipped with audio narration in Indonesian, has a variety of additional features that can support the implementation of the pilgrimage while in the holy land, can be used easily by using a personal smartphone, and the application will be available for free on google play store. Virtual reality is a recent trend for simulating some activity that has a limit (Sumardani, 2020).

\section{CONCLUSION}

The Free Hajj as a virtual reality-based Hajj ritual application helps the learning process of Hajj rituals because The Free Hajj will learn how to perform Hajj not just theory but also presenting the idea, practice and actual conditions such as being directly in Mecca.

\section{ACKNOWLEDGEMENTS}

We gratefully acknowledge funding support from the Hibah Penugasan Program Kreativitas Mahasiswa 5 (Lima) Bidang Tahun 2020 - Kementerian Pendidikan dan Kebudayaan Indonesia under the contract number 060/E2/PPK/SPPK/PKM-B2/2020. This product was presented in PIMNAS 2020 and get PIMNAS Gold Medal From Kementerian Pendidikan dan Kebudayaan Indonesia. 


\section{REFERENCES}

[1] Achmad, W. (2020). Peran dan Tantangan Pendidikan Agama Islam di Era Pandemi Covid-19 pada Lingkungan Keluarga.Journal Of Islamic Education, 5(2):169-182.

[2] Huda, N. (2019).Labbaik VR, Simulator Haji Pertama di Dunia, 7 agustus. Available at https://islami.co/labbaik.

[3] Humas Setkab (2019).Kuota Ditetapkan 221.000, Calon Jemaah Haji 2019 Wajib Rekam Biometrik di Tanah Air.22 Januari. Available at https://setkab.go.id/kuota.

[4] JPPN. (2019). Manasik Haji Dilakukan 10 Kali.21 April. Available at Available at https://jppn.com/news/manasik.

[5] Masruroh, L. and Ma'ruf, M. (2020) Strategi Guru Dalam Memotivasi Hafalan Juz 30 Santri Madrasah Diniyah Hidayatul Mubtadi'in Blawi Masangan Bangil. Journal of Islamic Education (JIE), 5(1): 89-99.

[6] Yusoff, M.F., Zulkifli, A.N., \& Mohamed, N.F. (2015). The model of persuasive hajj learning environment.Jurnal Teknologi,5: 141-147.

[7] Mohd, A. et al. (2012). Avatar Implementation in Virtual Reality Environment Using Situated Learning for "Tawaf".Procedia - Social and Behavioral Sciences. Elsevier B. V, 67: 73-80.

[8] Mulyana, W.W.,\&Gunawan, T.S. (2010). Hajj crowd simulation based on intelligent agent.International Conference on Computer and Communication Engineering, ICCCE'10: 11-13.

[9] NU. (2019) Virtual Reality Haji Berikan Pengalaman Personal Calon Jemaah Haji, 22 Agustus.Available at https://nu.or.id/110108.

[10] Ridarineni, N. (2014).Perlukah Manasik Haji Diberikan Lagi di Tanah Suci?.28 September.Available at https://ihram.co.id/berita.

[11]Rif, B. (2020). Contextual Learning Strategy in the Digital Era at Aisyiyah Fullday Elementary School, Klaten.Al-hayat: Journal of Islamic Education (AJIE), 4(2): 151-182.

[12] Sugiono (2017) Metode Penelitian Kuantitatif Kualitatif dan R\&D. Alfabeta.

[13] Sumardani D, Putri A, Saraswati R.R., Muliyati D, Bakri F. (2020). Virtual Reality Media: The Simulation of Relativity Theory on Smartphone. Formatif: Jurnal Ilmiah Pendidikan MIPA, 10(1): 13-24.

[14] Yasin, A. M. et al. (2010). Avatar implementation in virtual reality environment using situated learning for "Sa' $i$ " (Muslim Hajj Ritual).2010 International Conference on Educational and Information Technology Proceedings, 2: 286290. 